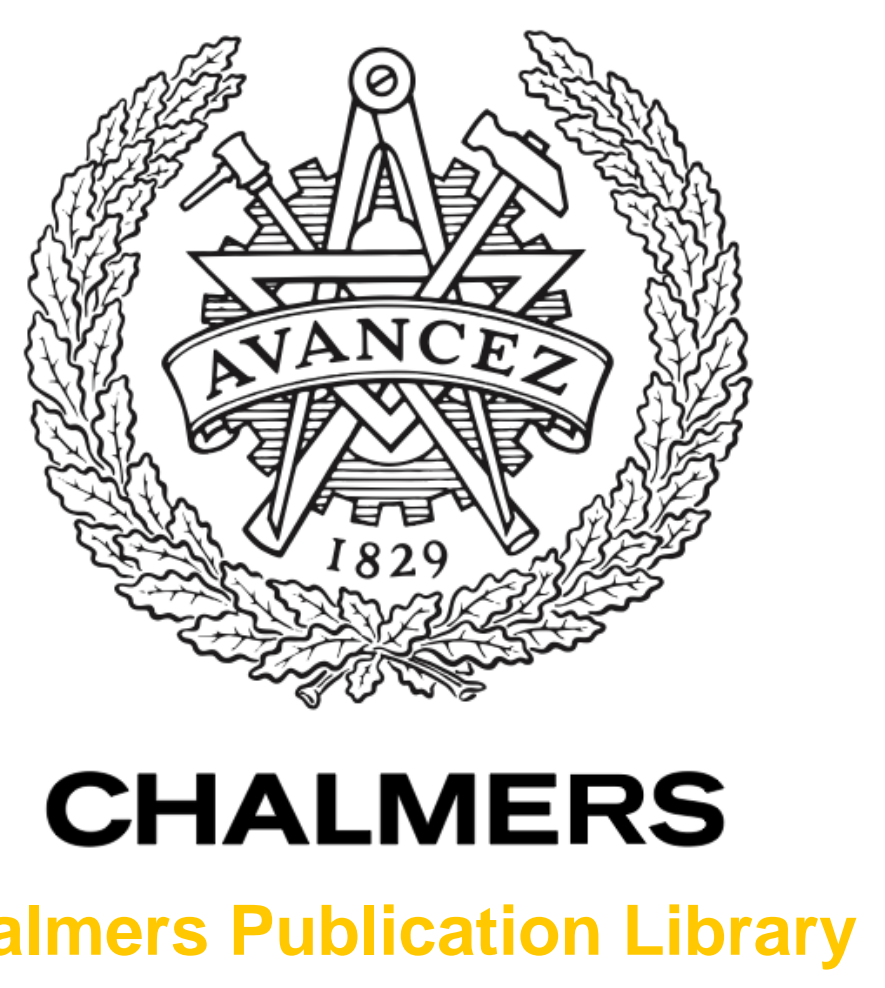

Chalmers Publication Library

\title{
The Diffusion of Renewable Energy Technology: An Analytical Framework and Key Issues for Research
}

This document has been downloaded from Chalmers Publication Library (CPL). It is the author's version of a work that was accepted for publication in:

Energy Policy (ISSN: 0301-4215)

Citation for the published paper:

Jacobsson, S. ; Johnson, A. (2000) "The Diffusion of Renewable Energy Technology: An Analytical Framework and Key Issues for Research". Energy Policy, vol. 28(9), pp. 625640.

http://dx.doi.org/10.1016/S0301-4215(00)00041-0

Downloaded from: http://publications.lib.chalmers.se/publication/245979

Notice: Changes introduced as a result of publishing processes such as copy-editing and formatting may not be reflected in this document. For a definitive version of this work, please refer to the published source. Please note that access to the published version might require a subscription.

Chalmers Publication Library (CPL) offers the possibility of retrieving research publications produced at Chalmers University of Technology. It covers all types of publications: articles, dissertations, licentiate theses, masters theses, conference papers, reports etc. Since 2006 it is the official tool for Chalmers official publication statistics. To ensure that Chalmers research results are disseminated as widely as possible, an Open Access Policy has been adopted.

The CPL service is administrated and maintained by Chalmers Library. 


\title{
The Diffusion of Renewable Energy Technology: An
}

\section{Analytical Framework and Key Issues for Research}

\author{
Staffan Jacobsson and Anna Johnson \\ Department of Industrial Dynamics \\ School of Technology Management and Economics \\ Chalmers University of Technology \\ 41296 Gothenburg \\ Sweden
}

Telephone: 4631 7721213,1222

Fax: 46317721237

E-mail: stja@mot.chalmers.se

anjo@mot.chalmers.se 


\begin{abstract}
During the last two decades there has been a great deal of research on renewable energy technologies. It is commonly thought that very little has come out of this research in terms of commercially interesting technologies. The first objective of this paper is to demonstrate that this perception is no longer entirely correct; in the 1990s there has been a double digit growth rate in the market for some renewable energy technologies. The consequent alteration in the energy system, is, however, a slow, painful and highly uncertain process. This process, we argue, needs to be studied using an innovation system perspective where the focus is on networks, institutions and firms' perceptions, competencies and strategies. The second objective of the paper is therefore to present the bare bones of such an analytical framework. A third objective is to identify a set of key issues related to the speed and direction of that transformation process which needs to be studied further.
\end{abstract}




\section{Introduction}

The energy sector is subject to a set of parallel and interacting forces of change. The most fundamental is awareness of the environmental consequences of the existing energy system. Fossil fuels and their role in acidification and global climate change figure prominently in the contemporary environmental and energy debates. The threat of nuclear disasters and problems with radioactive waste disposal are other issues that have received much attention. As a response to this, a demand for 'green' energy, is emerging.

Ever since the first oil crisis in 1973, there has been a great deal of experimentation with renewable energy sources. A considerable amount of government money has been spent on renewable energy $R \& D$, although just a fraction of the amount allocated to nuclear R\&D (OECD/IEA, 1997). A common reaction is, however, that very little has come out of that research in terms of commercially interesting energy technologies. ${ }^{1}$ This perception was entirely correct in the $1970 \mathrm{~s},{ }^{2}$ it remained broadly true in the 1980s but is now becoming increasingly incorrect.

The purpose of this paper is threefold: a) to demonstrate that a process of diffusion of a set of renewable energy technologies is now beginning to take place, which may indicate that we are entering into an early stage of transformation of the energy sector, b) to identify the bare bones of an analytical framework for studying this

\footnotetext{
${ }^{1}$ See for instance the work of the latest Swedish Parliamentary Committee on energy, which almost ignored technical change in renewable energy technologies in spite of working with a time horizon of about 25 years.

${ }^{2}$ Indeed, the 1980 Swedish referendum on nuclear power took place in a context where the renewable technologies, apart from hydro power and bio energy, simply did not constitute an alternative.
} 
transformation process and c) to derive a set of questions which need to be answered regarding the speed and direction of the process.

The paper is structured as follows. In the next section, we will briefly describe a set of renewable energy technologies and give evidence of sustained double-digit growth rates in the market for the new technologies. Section three provides elements of an analytical framework for studying how these new technologies may transform the energy sector. We emphasize that we need to apply an innovation system perspective when we analyse the processes of innovation and diffusion and that the emergence of a new, or transformed energy system, is a slow, painful and highly uncertain process. The analytical framework clearly departs from the conceptualisation of the process of technical change which is found in some of the literature on the timing of policy intervention for the purpose of reducing the emission of greenhouse gases. The final section outlines a set of issues which need to be researched if we are better to understand the transformation of the energy system into one which incorporates a larger share of renewable energy technology. These issues are the creation of variety, the process of institutional change and the emergence of 'prime movers.'

\section{The diffusion of renewable energy technologies}

In spite of a small decrease in the early 1980s, the OECD total primary energy supply (TPES) increased by 20 percent between 1980 and 1996, from approximately 45,000 TWh to 58,000 TWh (OECD, 1997 and OECD, 1998) $)^{3}$. The relative contributions of different energy sources to the TPES did not vary much during the period studied; in

\footnotetext{
${ }^{3}$ All data on the OECD level in this section comes from these sources; the 1980 data comes from OECD (1997) and the 1996 data from OECD (1998).
} 
1996 as well as in 1980, fossil fuels ${ }^{4}$ dominated the OECD energy market, representing 91 percent of the total supply in 1980 and 83 percent in 1996 . The proportion of nuclear power increased from approximately 4 percent of the TPES in 1980 to 11 percent in $1996,{ }^{5}$ and the contribution of renewable energy sources ${ }^{6}$ increased slightly from 5 to 6 percent during the same time period.

In absolute numbers, the contributions of fossil fuel (especially fossil gas) as well as nuclear power increased sharply from 1980 to 1996. The changes in the supply of renewable energy sources were much smaller. Moreover, it is primarily the renewable energy sources that were already established at the beginning of the period (hydro power, geothermal power, and combustible renewables and waste) that have contributed to this increase. This seems to confirm the belief that the 'new' renewables (wind and solar power etc.) have not yet reached a widespread market.

The total market is, however, much too large for even radical changes in the rate of diffusion of new, and still marginal energy solutions, to be noticed. In order to demonstrate that the picture painted above is unnecessarily dismal, we will give evidence of the rate of diffusion of some of the renewables, namely bioenergy, ${ }^{7}$ wind power, solar thermal energy and solar photovoltaic energy. With the exception of bioenergy, these renewables belong to the 'new' renewables. Bioenergy is, in

\footnotetext{
${ }^{4}$ Here defined as OECD classes "crude oil+NGL+feedstocks", "coal", "petroleum products" and "gas" due to the presentation of data in the OECD statistics. For detailed definitions see OECD (1998). 5 In the OECD statistics, the primary energy supply from nuclear power is defined as "the primary heat equivalent of the electricity produced by a nuclear power plant with an average thermal efficiency of 33 percent" (OECD, 1998).

${ }^{6}$ Here defined as OECD energy classes "geothermal, solar, etc", "combustible fuels and waste" and "hydro", due to the presentation of data in the OECD statistics. For detailed definitions see OECD, 1998.

${ }^{7}$ We have chosen not to divide bioenergy into 'biomass for electricity' and 'biomass for heat' primarily because the use of biomass for electricity production is quite a recent phenomenon.
} 
contrast, a traditional energy source which has a widespread use, but the field is still interesting to study since it is now being enriched by new technical solutions and applications and, thus, is in a state of quite significant change.

In the case of bioenergy, we will examine the case of Sweden. ${ }^{8}$ The contribution of bioenergy to the total energy supply was approximately 91 TWh in 1997 (see figure 2.1), which amounts to 19 percent of the supply of energy (STEM, 1998).

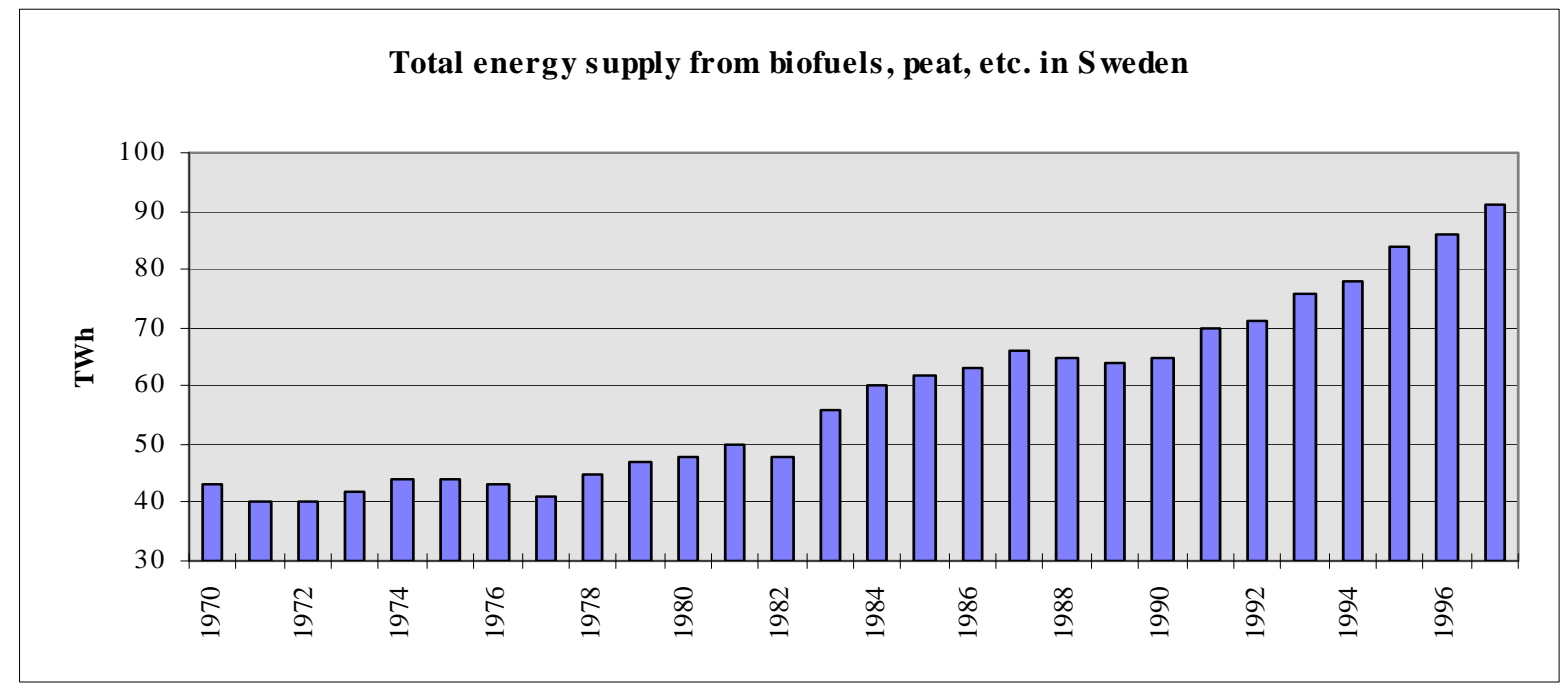

Figure 2.1: Total energy supply from biofuels, peat etc. in Sweden. (Source: STEM, 1998)

Since the oil crisis of 1978, the supply of energy from biomass has had an average annual growth of 3.8 percent. Even though the growth rate is rather low, the large base makes the growth in absolute numbers impressive as compared with other energy sources, especially other renewable ones. For instance, in 1995, the energy

\footnotetext{
${ }^{8}$ The choice of Sweden was made due to the availability of data; even though the use of biomass for energy purposes is widely spread in the world, we have not been able to find any longitudinal World or European statistics.
} 
supply from biomass and peat in Sweden increased with roughly 6 TWh, which was 1.3 percent of the supply of energy (STEM, 1998).

In a European perspective, this is a very high figure. In 1997 the total bioenergy capacity was approximately 520 TWh in the European Union (European Commission, 1997a). This figure is, however, expected to have been tripled by the year 2010 (European Commission, 1997a), implying an expected average cumulative growth rate of almost 9 percent. This does not appear to be unreasonable since there are some very interesting developments with respect both to technology and to how new applications are found for biomass. Biomass is increasingly being used in combined heat and power production and more advanced technical solutions based on gasification are being developed and tested for this purpose. For single households, pellet burners are increasingly available (at least in Sweden) and a whole new system based on a set of complementary technologies is currently evolving. ${ }^{9}$

Wind energy is probably the fastest growing renewable energy source in the world. The average annual cumulative growth in power capacity was approximately 55 percent in the period 1980-1998 (see figure 3.2). However, the total installed capacity in 1998 was only approximately 10 GW (BTM, 1999). The situation for wind energy is, thus, the opposite to that of biomass; the relative growth is high, due to the small initial stock, while the growth in absolute numbers is low.

\footnotetext{
${ }^{9}$ The evolution of a whole 'bioenergy chain' does not take place without considerable opposition from vested interest groups.
} 


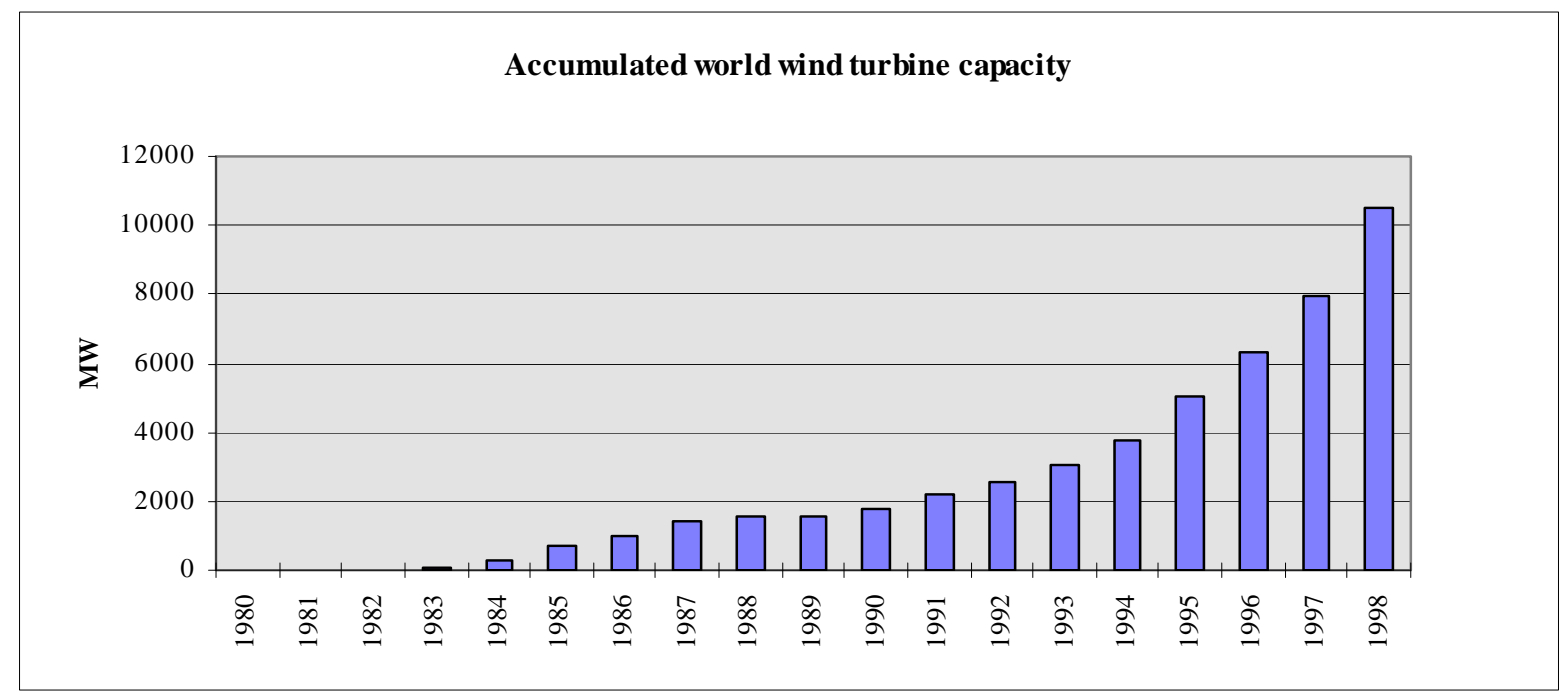

Figure 2.2: Accumulated wind power capacity in the world. (Source: Kåberger (1997) ${ }^{10}$, European Commission (1997b), table 2-2 and BTM (1999), table 2-2)

Today, wind power is often subsidised, but it is approaching a cost level that makes it economically attractive compared to established energy production methods, assuming good wind conditions. As the experience curve of electricity produced by windmill is not entirely flat (a proposed ratio of 0.91 according to Neij (1997)), we can expect its price competitiveness to improve.

The further diffusion of wind energy will not only involve continued expansion on land and the replacement of old plants with new and more productive ones but will also mean exploiting of new location possibilities by building ocean based wind power plants. This new possibility may give wind power a much higher growth potential. There are already test installations in, for example, Sweden and Denmark, and there are plans for 500 commercial wind power plants producing 2 TWh to be built off the west coast of Sweden (Holm, 1997). 
The demand for solar thermal technologies using collector arrays for heat purposes increased from a little over 200,000 $\mathrm{m}^{2}$ in 1990 to 500,000 $\mathrm{m}^{2}$ in 1994 in Europe. This corresponds to an annual cumulative growth of about 15 percent. Of this increase, the German market accounted for about half. The stock of solar collectors in Europe was about 4.6 million $\mathrm{m}^{2}$ in 1994 (see figure 2.3), ${ }^{11}$ corresponding to an energy supply of roughly 2.7 TWh/year (ESIF, 1995). The stock in Japan and US was approximately 6 and 5 million square meters respectively which suggests that the world production of energy by solar collectors is roughly $9 \mathrm{TWh} /$ year.UPDATE

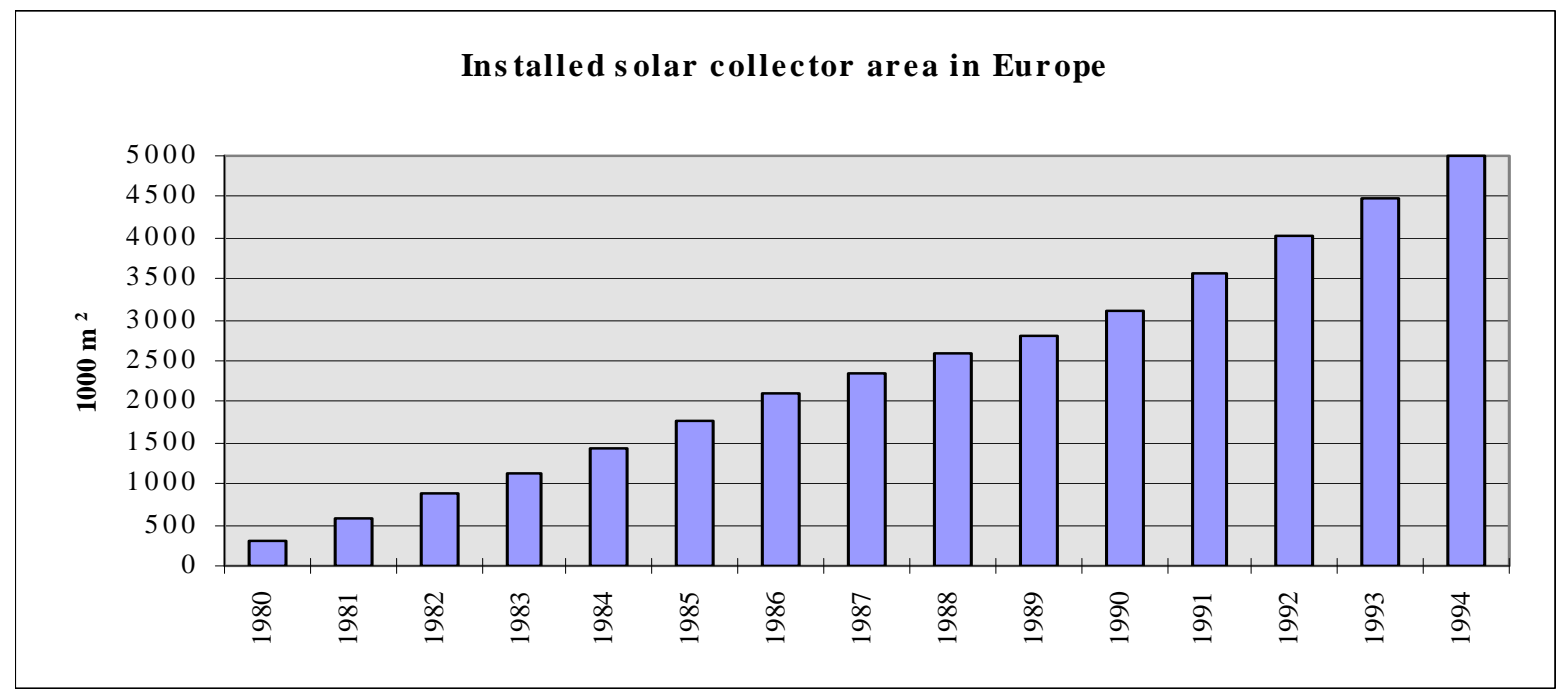

Figure 2.3: The stock of solar collector area in Europe (Ekvall et.al, 1997).

Solar collector technology is regarded as a fairly mature technology but some developments are taking place with respect to material technology and design. The chief bottlenecks for a massive diffusion (without subsidies) are a lack of standards (which often make the sale of a system custom specific), inadequate attention given to

\footnotetext{
${ }^{10}$ With the original source being Gipe (personal communication and printout)

${ }^{11}$ Excluding approx. 1.3 million $\mathrm{m}^{2}$ of unglazed collectors.
} 
design for manufacturability (i.e. it is difficult to assemble), lack of incorporation of solar panels into the design traditions of architects and an absence of scale economies in the firms producing solar panels. Many of these problems can presumably be handled by a large customer or set of collaborating customers within the context of an intelligent procurement, and such projects are under way.

Solar photovoltaic energy technology is the youngest new technology to be considered here. Only about 1 TWh was produced in the world in 1995, but the average annual cumulative growth of power capacity has been substantial, roughly 22 percent in the 1990s (se figure 2.4). Whereas the price/performance characteristics so far only satisfy some small segments (e.g. clocks and some off-grid applications), it seems possible that solar cells will become attractive in one (or several) larger market segment(s) in a not all too distant future (e.g. on-grid applications close to users) (UPGV 1994). This would, of course, open up for a more rapid market growth.

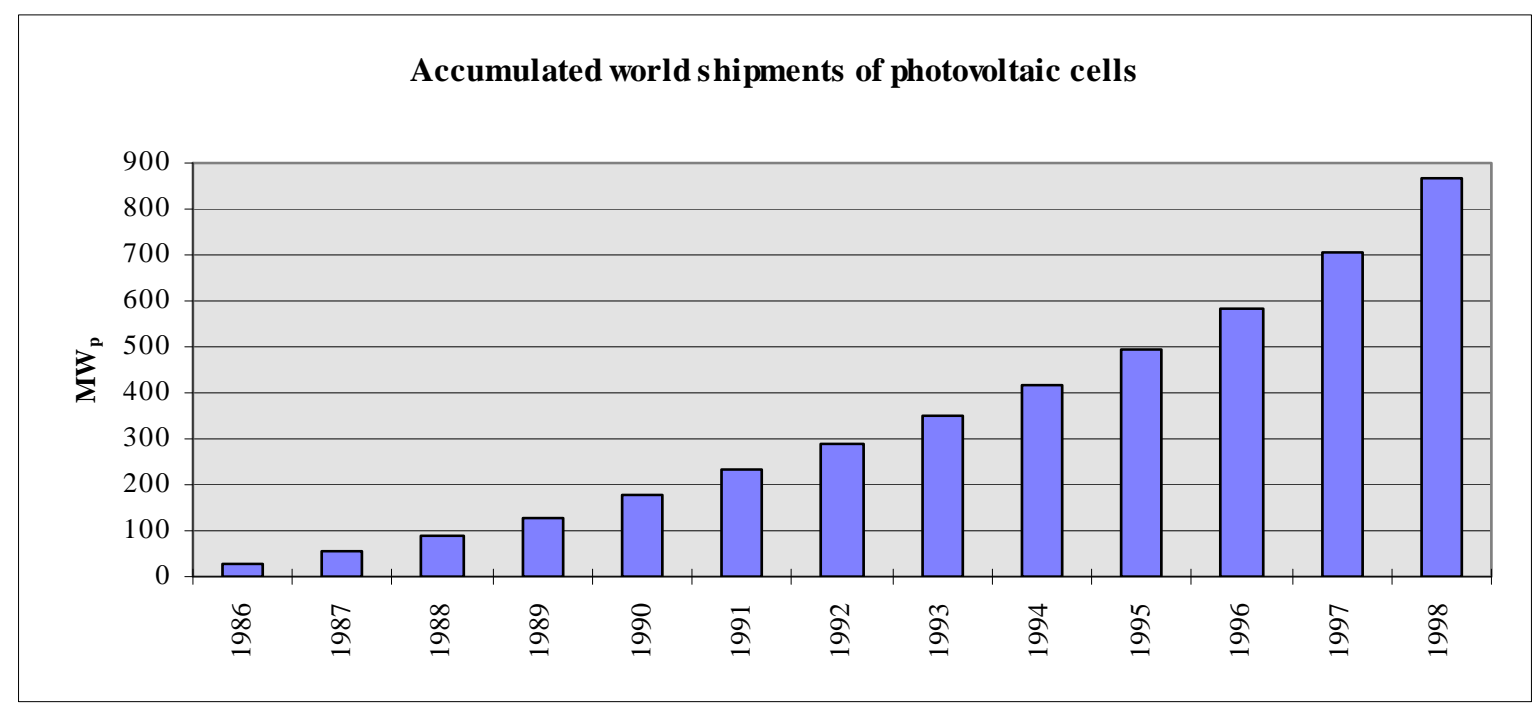

Figure 2.4: Accumulated world shipment of photovoltaic cells (Source: Elaboration on Andersson and Jacobsson (1997) and Curry (1999)). 
Today, the diffusion of photovoltaic cells is mainly hindered by high cost, and the demand is primarily driven by government procurement projects (Andersson and Jacobsson, 1997). As the experience curve is quite steep (Neij, 1997), it is essential to increase the accumulated production volume so that costs can be lowered. Thus, some kind of intervention (e.g. subsidies or procurement projects) will continue to be needed for some time, and there are several programmes (e.g. the ”70,000 roofs program” in Japan and the "Million Roofs Initiative” in the U.S.) aiming at sustaining the growth.

In conclusion, we have demonstrated that the 1990s have seen a very substantial diffusion of renewables. Yet, in most cases the growth is not self-sustained. There are still significant obstacles to be overcome in order to reach the stage where the diffusion of renewable energy technologies is not dependent on government interventions and where renewables have made a major inroad into the energy market. In order to clarify these obstacles, it is necessary to develop an analytical framework for analysing the process of transformation. The bare bones of such a framework will be given in the next section.

\section{Elements of an analytical framework for studying the transformation of an energy system}

The process by which a new technology emerges, is improved and diffused in society can be studied from a number of perspectives. The neo-classical economic perspective focuses on how changes in relative prices influence technology choise. In 
contrast, seen from the perspective of the individual firm the entrepreneurial act is the central feature of innovation and diffusion. These perspectives are not irrelevant, but we will develop one which not only takes relative prices and entrepreneurial acts into account but also emphasises that:

- the innovation and diffusion process is both an individual and a collective act (Saxenian 1994), and that

- the determinants of technology choice are not only to be found within individual firms, but also reside in an 'innovation system' which both aids and constrains the individual actors making a choice of technology within it. This 'innovation system' includes a large number of variables apart from prices.

It is the character of this system that we need to comprehend if we are to understand how an energy system is transformed.

Since 1987, when Christopher Freeman published his book on the 'Japanese Innovation System', a set of system approaches has been put forward, primarily in the economics and management of innovation literature. Some take the country as the unit of analysis and imply that differences in their 'national innovation systems', i.e. institutional set-up and structure of production, influence the technology choices made by individual firms (Porter, 1990; ${ }^{12}$ Nelson, 1992; Lundvall, 1992; Edquist, 1997). Others focus on regional innovation systems and elaborate more on cultural variables (Saxenian, 1994; Maskell, 1997). Yet others have for some time studied industrial networks, where firms are connected in long lasting relationships

\footnotetext{
${ }^{12}$ Porter (1990) uses a different terminology than the National Innovation System school, but is very closely related to it.
} 
(Håkansson, 1987). Finally, some authors focus on ‘technological systems’, systems

built around specific technologies or products (Hughes, 1983; Granberg, 1997;

Lundgren, 1991;13 Carlsson, 1995 and 1997; Holmèn and Jacobsson, 1997).

This latter system approach is, thus, technology specific. This means that there are many technological systems in a country or region, and that some actors are involved in several of them. Each of the technological systems is seen to be unique and they vary in their ability to develop and diffuse new technology. The technology-specific feature of the systems makes this approach attractive when the focus of the enquiry is competition between various technologies to perform a certain function, in this case the supply of energy. Thus, we would be able to study the characteristics of the specific system associated with an emerging technology, e.g. wind power, analyse its strengths and weaknesses as well as its dynamics and compare it with the system of an incumbent energy technology, e.g. electricity generation based on fossil fuels. ${ }^{14}$

Let us develop the notion of a technological system further. A formal definition of a technological system is (Carlsson and Stankiewicz 1991, p. 111):

".... network(s) of agents interacting in a specific technology area under a particular institutional infrastructure to generate, diffuse, and utilize technology. Technological systems are defined in terms of knowledge or competence flows rather than flows of ordinary goods and services. They consist of dynamic knowledge and competence networks”.

A technological system is thus made up of a number of elements:

\footnotetext{
${ }^{13}$ Lundgren's work was undertaken within the framework of the Uppsala network school but focused on the evolution of a specific technology, image processing, in Sweden.

${ }^{14}$ A local (national or regional) technological system in the energy sector may contribute to the solution of the global transformation problem by promoting local diffusion, thus solving a local problem and the nation's/region's part of the global problem. It can also promote global diffusion, for instance by exporting windmills or other technologies for exploiting renewable energy sources.
} 
- The actors and their competence, technical as well as other types of competence. Particularly important are the 'prime movers', i.e. actors that are technically, financially and/or politically so powerful that they can initiate or strongly contribute to the development and diffusion of a new technology. For instance, SAAB Aerospace was a prime mover in digital signal processing in Sweden and, later, Telia was a prime mover in the application of that technology to mobile phones.

- The networks, which constitute important modes for the transfer of tacit (Metcalfe, 1992) and explicit knowledge. These can be of various types. In particular, we may note networks that are conducive to the identification of new problems and the development of new technical solutions (often user-supplier networks), and more general information diffusion networks. Being strongly integrated in a network increases the resource base of the individual firm (in terms of information, knowledge, technology etc.) and, therefore, its degrees of freedom. The network also influences the perception of what is possible and desirable, i.e. images of the future, which guides specific investment decisions. At the same time, the network constrains the individual firm and sets limits to its technology choice (Lundgren and Nordenlöw, 1995).

- The institutions, which can be both 'hard' ones, such as legislation, the capital market or the educational system, or softer ones such as culture. The roles of the different institutions vary, of course; some institutions enable a high connectivity in the system, whereas other institutions influence the incentive structure. As is strongly emphasised in institutional economics (e.g. Edquist and Johnson (1997)), institutions greatly affect the specific path that a technology takes. 
We will exemplify the application of this approach with the system for factory automation in Sweden (see Carlsson and Jacobsson, 1993 and 1997a). In the 1970s and 1980s, there was a very fast diffusion of numerically controlled machine tools, industrial robots, flexible manufacturing systems and computer aided design units in the engineering sector. Sweden was extremely successful not only in terms of the extent of diffusion but also in terms of the international competitiveness of the supplier industry. Swedish firms gained large market shares in robotics, automatic guided vehicles, measurement systems, etc. Whereas it is clear that relatively high and rapidly increasing wage costs were a cause of interest in the new technology and that we can identify key entrepreneurial acts, the technological system was extremely supportive of these acts. We will elaborate on its key features, see Figure. 3.1.

First, Sweden housed some very advanced users of flexible automation technology. Volvo, SAAB and Asea (now ABB) were among those with a very high level of competence in the 1970s and they could well be argued to be the prime movers. Second, there were strong user-supplier networks where the users' ability to specify problems, and sometimes provide solutions (and create new firms via spin-offs), helped to create a strong supplier industry. Third, the supplier industry was strategic for Sweden in that it induced a fast adoption of the new technology among the large number of not so advanced firms in the home market. Fourth, there were well functioning bridging institutions which acted as nodes in the system, for instance The Swedish Institute for Production Engineering Research (IVF), Mekanförbundet (the industrial association for the Swedish engineering industry) and NUTEK (The Swedish Board for Technical and Industrial Development). They monitored and 
assessed new technology, provided meeting places and were centres for information exchange. Fifth, the academic sector was oriented towards applying the new technology in industry, i.e. this institution was supportive of a rapid diffusion. A system characterised by high competence and well developed connectivity was strongly conducive to the development and diffusion of new production technology.

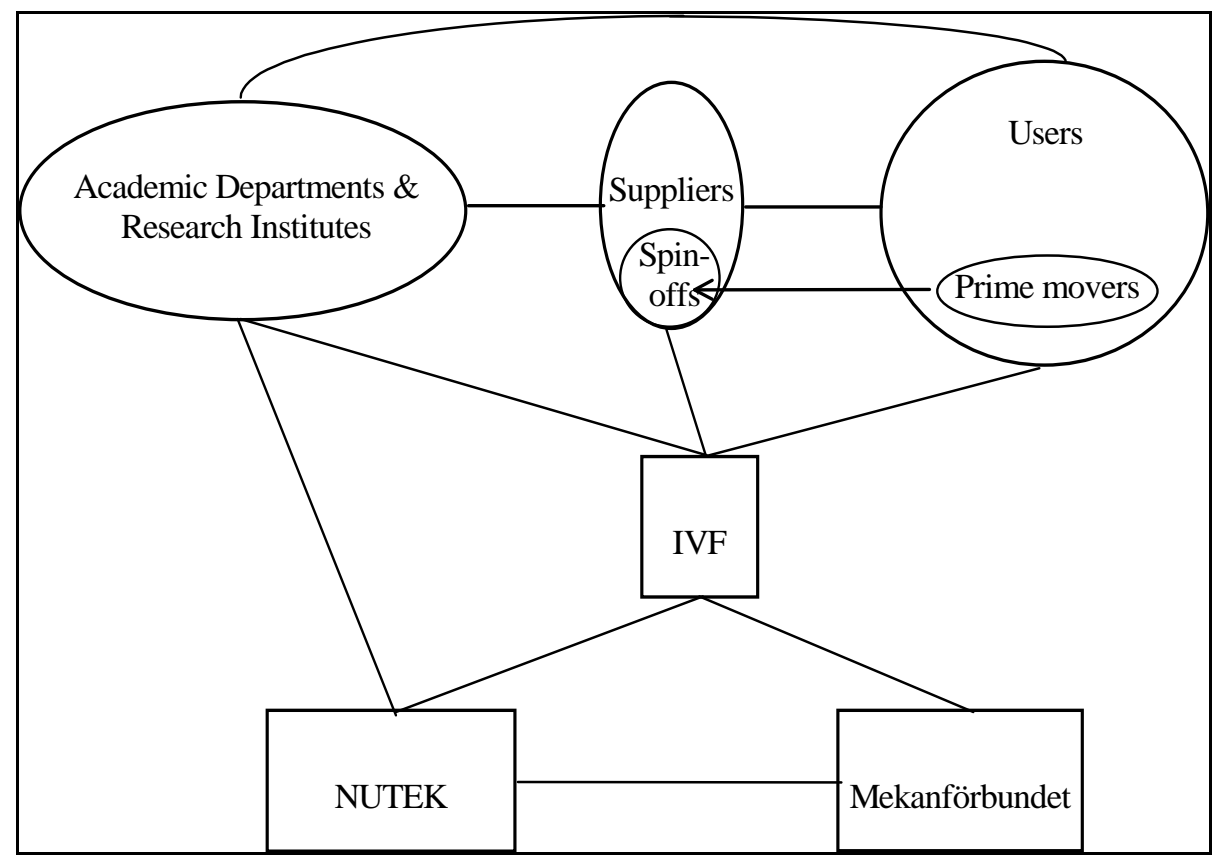

Figure 3.1: The technological system for factory automation in Sweden in early and mid 1980s

This brief example deals with a system which already exists. The essence of the formation of a new system is a process of increasing diversity in a situation characterised by the path dependent development (David, 1988) of the actors and the associated supporting institutions and networks. In general, therefore, the emergence of a new technological system is a long, uncertain and painful process. 
This would be expected to be particularly true for renewable energy technology since the market for energy is stagnating (at least in the OECD) and the new technologies substitute for rather than complement the existing technologies. Thus, renewables go against the perceived interest of the dominant actors in the electricity system (e.g. Preussen Electra in Germany) and their powerful lobbying capacity.

Before elaborating on a set of specific factors which may hinder the formation of a new technological system, let us briefly relate our approach to some of the literature in the energy field.

We conceptualise the process of technical change in a fundamentally different way than, for instance, Wigley et. al. (1997). First, the improvement in price/performance of a new technology is closely intertwined with the process of diffusion. A new technology often requires a long period of nurturing and diffusion before it achieves a price/performance ration that makes it attractive to larger segments in the market. In this process, there are feedback loops from an early diffusion of a new technology back to the development of its price/performance characteristics. Thus, the process of improving the availability of carbon substitutes, with an attractive cost level, ${ }^{15}$ involves a diffusion of renewables which, indeed, needs to go beyond that of exploiting extreme niche markets.

Second, we see technical change as endogenous to an economic system in which there are both inducement mechanisms (Dosi et. al., 1990; Grubb, 1997) and blocking

\footnotetext{
${ }^{15}$ For an elaboration on the conceptualisation of technical change see Ehrnberg and Jacobsson (1996) and Andersson and Jacobsson (1997).
} 
mechanisms. An inducement mechanism is, for instance, changes in relative prices or feedback from early users.

Third, the blocking mechanisms go far beyond those which for instance Schneider and Goulder (1997) label market failures. Not only do they only identify two market failures (whereas there are many), but they also ignore other sources of inertia. Clearly, the market constitutes but a limited part of the context for innovation and diffusion. Networks and institutions are also constituent parts of a technological system and influence, therefore, the processes of discovery and selection. Networks and institutions are, of course, neither neutral with respect to various competing systems, nor necessarily formed or reshaped endogenously or automatically. Just as markets fail, networks and institutions can fail to support the emergence of a new technological system.

Below, we will elaborate on a set of failures, which individually or taken jointly may repel a new technology. These failures are summarised in table 3.1.16

TABLE 3.1: Examples of factors leading to a new technology being repelled

ACTORS AND MARKETS
poorly articulated demand
established technology characterised by increasing returns
local search processes
market control by incumbents

\footnotetext{
${ }^{16}$ This is not an exhaustive list. Grubb (1997) discusses inertia caused by the structure of the capital stock and technological interelatendess.
} 


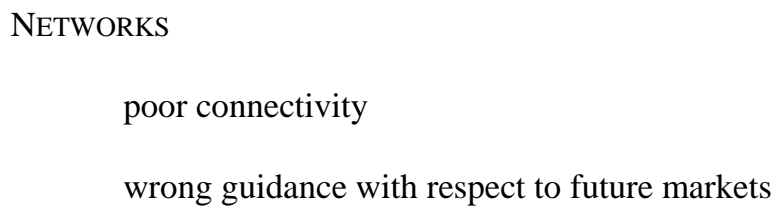

INSTITUTIONS

legislative failures

failures in the educational system

skewed capital market

underdeveloped organisational and political power of new entrants

Among the many sources of market failures, we will emphasise poorly articulated demand, economies of scale and experience and other sources of increasing returns, local search processes among the firms and market control by incumbents.

Markets are not necessarily formed in a spontaneous fashion (Galli and Teubal, 1997). In the early phase of the diffusion of a new technology, potential customers may not be able to articulate their demand (in terms of price/performance) and meet the supplier in the market place. Markets may therefore need to be created in a process where fragmented potential customers can formulate and articulate their demand. ${ }^{17}$

A new technology may also suffer from facing incumbent substitutes that have been able to undergo a process of increasing returns (Arthur, 1991). This tends to associate the new product with a high price (lack of scale and experience economies) or low 
utility (poor performance, lack of network externalities and/or infrastructure). If the

gap is very large, and if there is a paucity of nursing (Ericsson and Maitland, 1989) or bridging segments (Andersson and Jacobsson, 1997) that allow for a gradual generation of increasing returns, a new technology may never have the chance to rectify these initial disadvantages. ${ }^{18}$

Local search processes simply imply that firms build upon their existing knowledge base and other assets when they search for new opportunities. As Dosi (1988a, p. 225) puts it:

"... the search process of industrial firms to improve their technology is not likely to be one technology where they survey the whole stock of knowledge before making their technical choices. Given its highly differentiated nature, firms will instead seek to improve and to diversify their by searching in zones that enable them to use and to build upon their existing technological base.”

The slow changing nature of the technology base of a firm means that firms may not only search 'locally' and therefore restrict their technology choice to closely related areas, but they may be ignorant of opportunities which are at some distance; their vision may also be 'bounded' (Fransman, 1990). It may also mean that firms, which are aware of a new technology, may pursue risk assessments that are biased in favour

\footnotetext{
${ }^{17}$ This is probably the case in the Swedish market for solar collectors at the moment where there seems to be a need for bridges between the suppliers and potential customers forming 'mass market segments'.

${ }^{18}$ Again, in the case of solar panels in Sweden, there is an absence of increasing returns in many fields. The firms are so small that there is little feedback from sales to R\&D. Information is not diffused properly in the market. There is a lack of complementary industries, particularly in terms of knowledgeable plumbers who may inform customers, install the collectors and take responsibility for the installation (thus reducing uncertainty among potential customers).
} 
of their prevailing technology. This may, for instance, be due to a lack of appropriate ways of analysing the costs and benefits of a new technology. ${ }^{19}$

Market control by dominant incumbents means that the selection process may not involve a 'free' choice by customers. Take, for instance, the case of the rise of nuclear power in Sweden. As Kaiser (1992) notes, in the mid-1960s, a major threat to the diffusion of nuclear power was co-generation plants based on district heating. As a dominant actor, Vattenfall (the Swedish State Power Board) solved this problem by influencing the operating economics of many co-generation plants. ${ }^{20}$

Leaving market failures and turning to networks, these are important routes for the transfer of tacit (Metcalfe, 1992) and explicit knowledge. ${ }^{21}$ Networks can partly compensate for limitations in the firm's search space on account of both bounded rationality and bounded vision (Fransman, 1990). The network may also improve the resource base and the degrees of freedom of the individual firm (Håkansson, 1987 and 1989).

As noted above, networks do not necessarily grow spontaneously. As Saxenian (1994) argues, there may be institutional and organisational obstacles to the growth of

\footnotetext{
19 This has been argued to be the case of solar cells applied in a decentralised manner where there is not only a lack of knowledge of some of the benefits of such installations but also a problem of the investment routines in power utilities (UPGV, 1994).

${ }^{20}$ As Kaiser (1992, p.449) explains:

"Municipal energy companies that built cogeneration plants were 'punished' with unfavourable terms. Their cost of standby power was high, while the price paid for power delivered to Vattenfall was low. In contrast, companies that did not undertake to build cogeneration plants were offered favourable (but secret) power contracts with very low prices. As a result, the number of towns that actually built cogeneration plants stagnated during the 1960s. Thereby the door was opened for nuclear power and the power hierarchy with the electricity system remained intact.”

${ }^{21}$ This and the following paragraph are based on Carlsson and Jacobsson (1997b).
} 
a collective identity. To the extent this is the case, a 'weak' network failure would arise in the sense that firms are not well connected to other firms with an overlapping technology base. A different form of network failure - a 'strong ‘ failure - would be when individual firms are guided by others (i.e., by the network) in the wrong direction and/or fail to supply one another with the required knowledge. The source of a strong network failure lies in different assumptions concerning future (missing) markets among various networks. ${ }^{22}$ Thus, the other side of the coin of tight networks is that these can be characterised by considerable inertia, suggesting that there may be slow adjustment to new technological opportunities (Ehrnberg and Jacobsson, 1997)..$^{23}$

Coming to institutional failures, legislation may bias the choice of technology in favour of the 'incumbent' technology. Take for instance, the Swedish tax legislation which is biased against the production of electricity in combined heat and power generation plants, a feature of the legislation which is not surprising given the existence of large and powerful actors supplying nuclear and hydro-electric power.

The educational system may unduly support current firms and technologies as distinct from potential ones or it may simply fail to react quickly enough to the emergence of new generic technologies. The Swedish experience in electronics and computer

\footnotetext{
${ }^{22}$ When new technologies become available, providing expanded and different technological opportunities, the bounded (and different) visions (Fransman, 1990) of managers imply that firms and their networks may differ greatly in their perception of and ability to seize these opportunities. Rationality, on these assumptions, could well be argued to be not only limited but quite different among both firms and networks (Eliasson, 1990).

${ }^{23}$ A case in point may well be the choice to go for very large windmills in Sweden in the 1980s. According to members of the windmill community in Sweden, the choice of Swedish capital goods producers to go for MW size windmills (in contrast to the choice of Danish suppliers who chose very small turbines) was due to the relations developed with the dominant utilities in Sweden who were used to thinking in terms of large scale solutions.
} 
science is a case in point. As compared to the case of US, the Swedish educational system responded almost a decade later than the US which 'produced' more than three times the number of engineers in these fields per capita in the 1980s (Jacobsson, 1997).

The capital market may not respond 'spontaneously' in response to the need of a new technological system (Carlsson and Jacobsson, 1997b). Legislative change may be required to scale up the supply of capital, and competent capital will need to be created through a process of experimentation and learning. Capital is often supplied by larger firms who act as customers or partners (or even acquirers) of the smaller firms. The functioning of the capital market is therefore influenced not only by the specialised institutions supplying capital but also by the perceptions of the existing larger firms with respect to the new technology. ${ }^{24}$

Finally, a new technology may suffer from a lack of highly organised actors. Industrial associations may be lacking (which may lead to a weakness to articulate the need of legislative change), as may meeting places and fora for exchange of information and knowledge.

To conclude, the rate and direction of technical change - the process of technological choice - is decided in competition between various technological systems, both existing, fully developed and emerging ones. How the competence of actors changes and how institutions and networks are altered will shape the growth path of a new system and how well it can compete with other systems. The impact of general 
inducement forces, such as 'green customers', relative prices etc. is mediated through alterations in the elements of the emerging technological system and presumably need to be of considerable strength to overcome the obstacles outlined above. Obviously then, the transformation process is a very open-ended process which can take many directions, not only due to the inherent difficulties in assessing the future improvements in technology but also in the many ways in which competence, institutions and networks may evolve.

\section{What do we need to know more about - key issues in the transformation process}

It is plain that there are a large number of forces that may block formation of a new technological system. These forces may work independently but are likely to reinforce one another; ${ }^{25}$ market, institutional and network failures may combine into systems failure. This suggests that there is a wide range of questions that needs to be answered if we are to be able not only to understand the formation process better but also to influence its outcome.

In this section, we will discuss some central issues for the emergence of a new technological system based on renewable energy technology. The objective is, thus, to identify and discuss issues that need further elaboration before we can say that we truly understand the process of change in the energy sector. ${ }^{26}$

\footnotetext{
${ }^{24}$ A manager of a Swedish wind turbine producer underlined the decisive influence of the negative and even pejorative attitude of the business community towards wind turbines technology in the failure of his firm to find partners to exploit the growing market for that technology.

${ }^{25}$ For instance, legislative obstacles to the development of a venture capital market may hinder the development of competent capital, which would tend to lead to an under-exploitation of universities as a source of renewal through their spin-off of firms.

${ }^{26}$ For reasons of space, we have had to limit ourselves to three issues.
} 
First, transforming the energy system involves replacing, or supplementing, established technologies with new ones. A necessary condition for the development and diffusion of a new technology is that variety in the knowledge base is increased by means of experimentation. However, there is a considerable risk that that the existing configuration of competence, networks and institutions actually manages to hinder the process of creating variety (Carlsson and Jacobsson, 1997a). ${ }^{27}$ The existing systems may be 'locked in' to the established technologies due to the cumulativeness and path dependency of innovation, and actors may, therefore, not look for opportunities outside their traditional areas. If a search is undertaken within new areas it will probably be done in a highly 'localised' fashion. Thus, understanding how variety in the knowledge base is created and sustained is the first key issue for the transformation of the energy system.

Second, in the competition between an emerging new technological system and an incumbent one, the latter is supported by a whole set of institutions, for instance in the form of legislation favouring the incumbent technology. As underlined above, whereas institutions are malleable, they can not be expected to alter 'automatically' in favour of the new technology. Indeed, they can rather be expected to block it. The second key issue is, therefore, the process of institutional change and how that can be aligned to the needs of renewable energy technology.

Third, since the construction of a new system often involves the destruction of an alternative system (Hughes, 1983), actors within the existing system can be expected 
to try to obstruct the development of the new one, for example in the political arena. Hence, strong actors, or groups of actors, which can promote the new technology need to emerge. ${ }^{28}$ In other words, 'prime movers' are key actors in the creation of new technological systems. The third key issue is, therefore, the issue of how such actors emerge.

In the following section, we will discuss these three issues. In each of them, we will also include some reflections on policy. Illustrative examples are given mainly from Sweden and Germany.

\subsection{The creation of variety in the knowledge base}

In the energy sector, government $R \& D$ programmes and $R \& D$ pursued by the utilities have been significant ways of generating new knowledge, in addition to the R\&D financed and pursued by the capital goods industry. Government funded R\&D has, however, declined greatly in the past decade and, moreover, this mechanism has been poorly used to foster variety, at least in the sense of fostering renewable energy technologies. As is shown in figure 4.1, the OECD governments are strongly biased in

\footnotetext{
${ }^{27}$ In other words, there may be feedback mechanisms whereby "...a selection process may consume variety" (Metcalfe, 1992, p.103).

${ }^{28}$ In the Swedish case, a constellation of actors shaped the process of exploiting hydropower. This consisted of Vattenfall, the electricity-intensive industry and the power equipment industry (Kaiser, 1992). It also had an academic part with significant research and teaching in, for instance, power electronics in both Stockholm and Gothenburg. Laws were shaped and institutions built to support the functioning of a technological system based on hydropower. Many of the same actors were part of the process of building a nuclear power industry from the 1950's onwards and the same actors are now objecting to the growth of an energy system based on renewable energy sources, apart from hydropower.
} 
the funding of R\&D to nuclear technology and there has really been no change in the figures over the period studied.

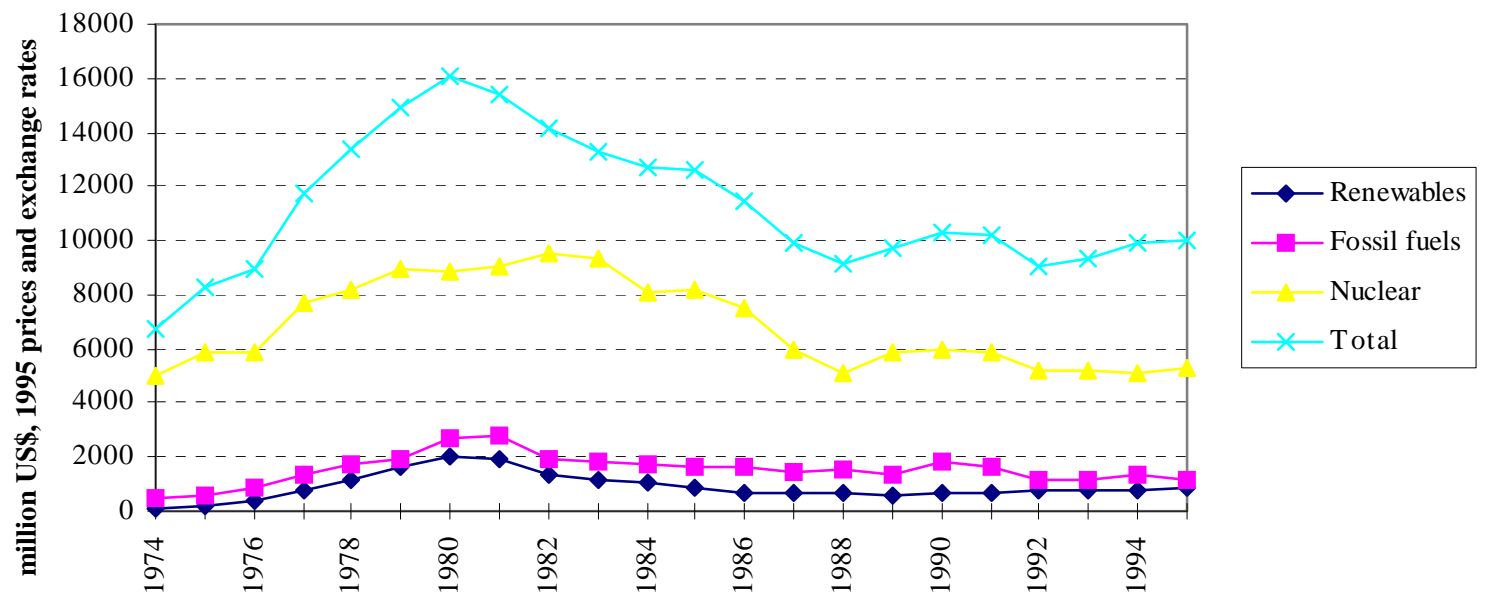

Figure 4.1: The distribution of Government fund for R\&D in the energy sector in the OECD countries, 1970-1995. (Source: Elaboration on OECD/IEA (1997))

Additionally, utilities are presumably reducing their R\&D in the light of the deregulation, and the suppliers of renewable energy technologies are not always large firms with enough skill and capital to break new ground. Policy, therefore, needs to be formed to make sure that there is funding for new knowledge creation and that there are actors willing to do the research.

In designing programmes for that purpose, it might be tempting for policy makers to try to make sure that the available resources are used "effectively" by guiding the search for new knowledge in very specific directions. However, in a situation characterised by technological uncertainty it is important to have initial variety even within technological fields (e.g. several different wind turbine or solar collector 
designs). Thus, policy should stimulate the development of different designs rather than trying to make ex ante identifications of the 'optimal' design.

Policy may also be concerned with improving the linkages in the system so that existing knowledge can be widely diffused, opening up for additional experiments by new actors. ${ }^{29}$ The degree of connectivity in existing networks influences, of course, the amount of information and knowledge that is diffused in the system. A high connectivity is not, however, automatically created by market forces but is based on the development of trust and a collective identity. Creating bridging institutions and fostering a collective identity is, thus, an important task for policy as may be the formation of entirely new networks.

Indeed, the formation of new networks can be central to the process of fostering variety in that the diffusion of knowledge through such networks can have very dynamic effects. The case of wind power in Denmark is an interesting example of this phenomenon: Organised user groups demanded reliability and safety, thus influencing the manufacturers' designs of wind turbines; manufacturer competence was built in co-operation with users through learning-by-doing and learning-by-using; a competent supplier industry was also founded by interaction and knowledge-sharing between manufacturers and firms supplying specialised components (for example fibre-glass blades); and the government intervened to support the creation of this network. $^{30}$

\footnotetext{
${ }^{29}$ For example, much of the governmental funding has gone into academic research has never been put to use by the researchers themselves or transferred to the industry.

${ }^{30}$ This paragraph is based on Karnoe and Garud (1997).
} 
With reference to the formation of networks, a particularly vital element in policy is the shaping of new and strong user-supplier links. In connection with this, it is very interesting to note the experiments undertaken by the Swedish Board for Technical and Industrial Development in organising various collective procurements of energy efficient goods. A central idea in such efforts is to connect fragmented users and help them to formulate and articulate their latent demand, i.e. to create or improve the functioning of the market. A new energy system based on many technologies and involving many actors, some of which are small and poor in resources, would seem to be an excellent arena for applying such a policy more extensively. Indeed, there is currently a discussion in the International Energy Agency of joint procurement with respect to solar collectors (Westling, 1997). In that process, new network links can be forged and the resulting links can have a long term beneficial effect which go way beyond that which accrues to the initial partners.

\subsection{The process of institutional change}

As mentioned above, existing institutions may very well block the development and diffusion of new technologies. Take, for example, the issue of building permits for wind turbines. This is one of the most serious obstacles to the diffusion of wind turbines both in Sweden and in the Netherlands. In Sweden, present legislation gives ample opportunities for anybody to file a complaint and take the issuing of a permit to court. ${ }^{31}$ In the Netherlands, there are huge problems to find on-shore locations for wind turbines; although the provincial authorities have allocated areas for wind energy, the municipal authorities have other priorities and hesitate to issue permits (Johnson and Jacobsson, 1999b). 
This example shows how closely related institutional change is to policy. This is not only the case with legislation - many other institutions (e.g. the capital market and the educational system) are also strongly influenced by policy. A number of observations can be made as regards the relations between institutional change and policy in connection with renewable energy technology.

First, in the process of adjusting the institutional set-up in favour of the emerging technological system, policy makers need to be patient, as the time scale involved is probably very long. Even in the best of cases, the transformation process will take decades and require tenacity from policy makers to shape the institutional context. Take, for example, the German experience in wind power. Germany has been the leading market in the world in the 1990s and is the only country that has generated a supplier industry which can challenge the Danish industry. The process has been led by policy measures which have altered the institutional set-up in a number of ways, of which we will mention three; i) the diffusion process was stimulated through subsidies from 1989; ii) from 1991, a law (the Electricity Feed Law) guaranteed wind turbine owners a fixed and high price for electricity supplied to the grid; iii) the government ensured that land was allocated for the use of wind turbines. Yet, even though these alterations induced a very fast rate of diffusion of wind turbines in Germany for about a decade, only a fraction of the electricity supplied comes from that technology and, moreover, the technology is still challenged by actors in the incumbent technological system.

${ }^{31}$ In spite of this, the Swedish government has neither taken any initiative to change the legislation nor 
Second, this case also illustrates the need for variety and consistency in the applied policies. The three measures mentioned above were only a part of a larger policy 'portfolio' aiming at changing the institutional framework, e.g. the incentive structure, in order to support technology diffusion and industry development. Hence, there was a great variety of instruments used by the German government. When implementing such a portfolio it is crucial that the different instruments are consistent with one another. In this case, industry policy and market stimulation measures went hand in hand and created a positive feedback-loop, but policies may just as well turn out to counteract one another.

Third, a central aspect of the process of institutional change is the struggle in the political arena between proponents of the new and the incumbent technological systems. We will exemplify this with the story of the German Electricity Feed Law. ${ }^{32}$

When it was discussed and later passed by the Bundestag about 1990, no one (and in particular not the large utilities), could foresee the tremendous impact it would have on the rate of diffusion. Thus, the potential implications of the institutional change were not understood and there was little response from the actors in the incumbent technological system. ${ }^{33}$ However, with the rapid diffusion of wind power in the early 1990s, the larger utilities began to realise that the new technology constituted a threat and a struggle began to change the Feed law.

made sure that land is allocated for wind turbines in another way.

32 This and the following two paragraphs are based on Ahmels (1999) and Molly (1999).

${ }^{33}$ In the Swedish case, similar proposal were made in the 1980 s but they did not get a majority in parliament (Carlman, 1990). This difference was probably linked to a heightened awareness of, and sensitivity to, any perceived threat to the Swedish nuclear establishment by renewable energy technology, since these had been portrayed as such by a number of governments ever since the referendum on nuclear power in 1980. On the contrary, in the German case, the institutional change was not implemented with the explicit aim of substituting nuclear power with wind power. 
In the meantime, however, the number of wind turbine owners had increased greatly in Germany and some local turbine manufacturers had emerged. These groups became well organised, and by teaming up with other associations in the renewable energy field they mobilised a large number of people to take part in the discussions over the future of the law. A very considerable effort was made by the German Wind Energy Association to seek out selected members of parliament and lay out arguments in favour of the law. In this process they were very much helped by the fact that wind energy had become the source of livelihood of a large number of people, in particular in the north-west of the country. Economic arguments could therefore be used, in addition to environmental ones.

In 1997, after years of debate, the Bundestag voted in favour of keeping the Feed law, but it was a very close call. The key factors here were, thus, i) an initial lack of confrontation between actors in the emerging technological system and those in the incumbent systems (fossil fuel and nuclear) ${ }^{34}$ and, ii) at the heart of the process, successful lobbying based in part on the growing economic importance of wind power. Of course, the economic importance of the new technology was due to earlier policies promoting wind turbines, which set in motion a process where the actors in the emerging technological system became strong enough to influence the institutional landscape on their own - policy contributed indirectly to the process of changing the institutional framework by fostering the development of strong actors or actor groups. 
Fourth, looking ahead, two fundamental features of the institutional set-up in the energy sector are the current deregulation of the electricity supply industry within the European Union and the future emergence of a joint European electricity market.

In general, a deregulation can be expected to lead to an altered technology choice.

Opportunities for the development of a system based on renewable energy technologies may, therefore, very well increase. In the US, deregulation is expected to lead to the closure of a number of nuclear power plants, which are not pricecompetitive with gas (Finanstidningen, 1997), and a similar trend has been seen in Britain (Stirling, 1997). The deregulation has also opened up the possibility for energy suppliers to differentiate their products in terms of the energy source, and a demand for 'green' electricity is beginning to grow, not only from private customers but also from firms. ${ }^{35}$ Hence, the introduction of competition may induce a segmentation of the market for electricity where an important dimension is how 'green' the energy is. ${ }^{36}$ A deregulation also opens up for new entrants into the energy field, be they farmers, co-operatives or firms diversifying into the energy market.

However, another result of the deregulation might be lowered prices for electricity, at least initially. In addition, the creation of a European market will challenge any

\footnotetext{
${ }^{34}$ This absence of an initial confrontation could be interpreted as being the result of a lack of foresight among the nuclear and coal lobby combined with a pro-renewable stance among the political parties after the Chernobyl accident. The timing of the policies were, thus, very appropriate.

${ }^{35}$ For example, SJ (the Swedish state-owned railway company) demanded that the electricity supplier should set up a wind turbine to supply roughly the energy to operate the trains on a 70 kilometre long line in southern Sweden. Such customer demands would hardly have been met in a monopoly market. (Nilsson, 1998).

${ }^{36}$ Indeed, an association of energy suppliers in the US suggests that customers demanding 'green' energy constitute a potentially large 'bridging' market for solar cells in the US, and recommend the exploitation of that market segment prior to any other (UPGV, 1994).
} 
national scheme for fostering renewable energy technology. The key institutional issue today is therefore to develop a Pan-European scheme, which will ensure favourable conditions for renewable energy technology even in the context of sinking electricity prices. Such a scheme should, tentatively, contain at least three elements: (1) ensured access to the grid for all producers of electricity, (2) a Pan-European certification procedure for renewable energy technology (to ensure a match between consumption and production of renewable energy) and (3) an attractive and predictable price for renewable energy. ${ }^{37}$ The experience with the German Feed law has been very positive as a law, in contrast to a temporary policy of subsidies, is more greatly predictable and therefore can be expected to attract more private investors to renewable energy technology.

\subsection{The formation of 'prime movers'}

Prime movers perform four important tasks to promote the new technology: they raise awareness, undertake investments, provide legitimacy and diffuse the new technology. Often, prime movers are located within the capital goods industry. A strong local capital goods industry can have additional beneficial effects on the local rate of diffusion in at least three ways. First, the capital goods industry often acts as an educator of users (Carlsson and Jacobsson, 1991). Second, a strong local supplier industry is in a favourable position to satisfy the, sometimes specific, demand from the local market. A case in point is the very powerful drive of the German wind turbine producers to produce very large windmills, which can be explained by the

\footnotetext{
${ }^{37}$ This implies that suppliers of electricity produced by means of fossil fuel, and perhaps also nuclear power, should be taxed in a manner which reflects their environmental effects.
} 
character of the local market. ${ }^{38}$ Third, a developed supplier industry can by force of its economic importance more easily influence the institutional set-up, as in the German wind turbine case (see section 4.2).

Turning to the case of Sweden, it is however not self-evident which actors may become prime movers within the field of renewable energy technologies. The suppliers are small, badly organised (unlike the German Industry Associations) and far from being able to influence the political process (Johnson and Jacobsson, 1999a). Moreover, they are technologically and financially weak as well as strategically nonaggressive. Thus, the individual firms cannot be expected to be able to take on the role of 'prime movers'.

As for the established actors within the energy field (both equipment suppliers and energy companies), they clearly have the competence, resources and influence to push the development of the new technological system. Sweden certainly has strong actors such as $\mathrm{ABB}$ and Vattenfall. ${ }^{39} \mathrm{ABB}$ (then Asea) earlier acted as a prime mover within the energy field, when it made a strategic commitment to nuclear power in the 1960s and, against all odds, came out as a major international supplier (Kaiser, 1992). So far, these actors have, however, more acted as obstacles to than proponents of renewable energy technology. The same is the case for major actors in some other countries, e.g. Preussen Elektra (energy company) in Germany (Ahmels, 1999).

\footnotetext{
${ }^{38}$ As the German market expanded, the available on-shore sites became scarce, which meant that the Germans had to economise the use of land and exploit sites with poorer wind conditions. Thus, it became necessary to build very large turbines.

${ }^{39} \mathrm{ABB}$ is a leading supplier of energy equipment and Vattenfall is the leading energy supplier in Sweden with a market share of approximately 50 percent.
} 
There are, however, some larger firms involved in renewable energy technology elsewhere. In the field of solar cells, Canon is the leading patentee in amorphous silicon cells (Andersson and Jacobsson, 1997), which may indicate that they will become a prime mover in solar cell technology. In Germany, two of the leading wind turbine producers were recently acquired by large firms (Enron and Balcke-Dürr of the Deutsche Babcock Group), which has allowed the wind turbine manufacturers to pursue a more aggressive strategy in terms of technology development and growth (Hansen, 1999; Müller, 1999). In the same field, some large firms (e.g. Thyssen) are now making investments in wind farms. ${ }^{40}$ Thus, there is some evidence of larger firms entering the industry, and these may have the ability and interest to become 'prime movers'.

Policy agents need, of course, to be concerned with the role that 'prime movers' can play with respect to the new technology. They need to assess whether or not 'prime movers' exist and encourage the establishment of local 'prime movers' that can act early. Policy agents also need to be concerned with the conditions under which a local supplier industry can prosper. The successful lobbying by the German wind turbine industry and owners (as related above), could not have taken place without a deliberate, and successful, policy of fostering the local capital goods industry (Johnson and Jacobsson, 1999b).

The role of ‘prime mover’ may not only be played by individual actors; constellations of actors is another possibility if a number of actors share an interest in promoting a

\footnotetext{
${ }^{40}$ These firms entered about a decade after wind turbines began to be diffused in Germany so they can not be argued to be prime movers from the start. However, their entry will give wind turbines more legitimacy and make it easier to mould the institutional framework to the needs of wind power.
} 
new technology. For example, when hydro power and, later, nuclear power were developed and diffused in Sweden there was a shared interest by many actors: the state, the electricity intensive industry, the suppliers of electricity and the environmental movement. ${ }^{41}$ Thus, as was mentioned above in the case of the Danish wind turbine industry, the role of networks in a transformation process might involve more than the transfer of knowledge; networks might also drive the process more actively, for example by influencing the nature of institutions.

If a future energy system is to be built on renewable energy sources, it will probably contain a varied set of technologies, presumably including various types of applications of bio energy, solar collectors, solar photovoltaic cells and wind power. It is also probable that these smaller-scale, more decentralised technologies will be exploited by a larger number of actors than in the case of nuclear power, coal and hydropower technologies. Indeed, the prime movers of renewable technologies might be clusters of smaller firms organised in new networks, which perhaps are specific to each renewable energy technology. Again, in the German case of wind power, farmers, smaller utilities and the infant wind turbine industry initially made up the new networks. 'Prime movers' in the form of larger firms were initially absent, but were substituted for by a combination of a very strong politically formed portfolio of economic incentives to install wind turbines (as was discussed above) and the activities of this new and growing network. Within other areas there could be different constellations of actors. For instance, one could well imagine that suppliers of solar collectors form networks with construction firms as well as with larger housing co-operatives. Another case may be a set of smaller utilities, which could

\footnotetext{
${ }^{41}$ They initially supported nuclear power as it was seen as a way of reducing the environmental
} 
collaborate with suppliers of gasified biomass technology in a joint procurement programme. A third possibility could be paper and pulp manufacturers who supply energy to municipal utilities through the gasification of black liquor.

However, it is not always clear which actor constellations have developed or could develop an interest in a transformation of the energy sector. Moreover, the new actors need to 'find one another' and form, perhaps entirely new, networks. The role of policy must therefore be to help actors to find one another and to stimulate the formation of new networks (see also section 4.1).

\section{Conclusions}

In spite of the oil crises and the long standing awareness of the environmental consequences of the use of fossil fuels, they still account for over 80 per cent of the total primary energy supply in the OECD countries and their use increased in absolute terms in the period 1980-1996. The share of renewable energy in the total primary energy supply is small in the OECD countries (six percent) and it rose only marginally in this period. Moreover, it is still the well established renewables (hydro and biomass) that account for most of the supply.

It is commonly thought that very few alternatives exist to fossil fuels, apart from nuclear power. The first objective of this paper was to demonstrate that that this perception is now not entirely correct, the diffusion of 'newer' renewable energy technologies is beginning to take place on a scale which is promising. This diffusion has so far essentially been driven by environmental factors and policy interventions 
and takes place in a context of general deregulation and internationalisation of the sector.

Wind power, solar cells, solar panels and new ways of using biomass are, thus, now beginning to make inroads on the energy market, as demonstrated by double digit growth rates in the 1990s. Indeed, wind power shows an explosive growth similar to that of mobile phones. Whereas much of the demand for these 'newer' renewables is linked to public procurement policies or subsidies, they are clearly improving their price/performance and their competitiveness with respect to fossil fuel and nuclear power. However, we are still at a very early stage of diffusion. The accumulated stock of windmills, solar panels and solar cells supplied about 20 TWh in 1996, or 0.04 percent of total primary energy supply in the OECD. A significant alteration of the vast energy system in the direction of using more renewable energy technologies is going to be a slow, painful and highly uncertain process.

The second objective of the paper was to present the bare bones of an analytical framework for studying this transformation process and to derive a set of questions for research as regards the speed and direction of that process.

We suggested that an analytical framework built around the concept of technological systems may be suitable. A technological system is a technology specific innovation system which is useful when the focus of the enquiry is to study the competition between various ways of supplying energy. The constituent parts of a technological system are actors and their competence, networks and institutions. The issue at stake is how a new system is formed, based on competence in a new technological field, 
involving reformed or new networks and institutions which support the new technology.

Not only market failures, but also network and institutional failures abound in the transformation process, blocking the evolution of a new technological system. Competence may not be developed due to local search processes, a poorly articulated demand may mean that markets are underdeveloped, the process of increasing returns may not be strong enough to bridge the price/performance gap to the incumbent technology, there may be weak connectivity between actors favouring the new technology or a potentially important actor is given the wrong guidance from his network as regards the new technology, legislation may favour the incumbent technology (and actors), the educational system and the capital market may do the same, etc. There are, thus a multitude of forces which favour an 'incumbent' energy system, forces which are likely to reinforce one another in a process of cumulative causation. The inducement mechanisms need to be strong enough to overcome these failures and set in motion a process of cumulative causation which works in favour of the new technology, as has happened in the Danish case of wind turbines.

Clearly, the transformation of an energy system towards one based on a substantial share of renewable energy technologies is highly uncertain and a whole set of questions needs to be raised, and answered, if we are not only to understand it better but also influence the outcome.

The third objective was to identify a set of issues which need to be researched. The first was the conditions under which variety in knowledge is generated and how that 
knowledge is diffused. We emphasise the risks of 'lock-in' effects and the role of networks in generating and diffusing new knowledge. The second issue is the process of institutional change. We underline its importance, the tenacity and ingenuity required by policy makers and the essentially political character of institutional change. The third issue is the emergence of 'prime movers' which can lead the transformation process. In particular, we emphasise the role that a local capital goods industry can play. The 'prime movers' can be both larger firms and networks of smaller firms. In scenario with a distributed energy system made up of a whole set of different technologies it may well be that networks take on the role of 'prime movers'. 


\section{Sources:}

Ahmels, H.P.(1999): Interview with Dr. Hans Peter Ahmels, chair of DEWI (the German Wind Energy Association), October 8.

Andersson, B. and Jacobsson, S. (1997): "The dynamics of technical change and the limits to the diffusion of solar cells”. Mimeo, Department of Physical Resource Theory and Department of Industrial Dynamics, Chalmers University of Technology, Gothenburg, Sweden.

Arthur B. (1988): “Competing technologies: an overview”. In: Dosi, G. et al (eds): Technical Change and Economic Theory. Francis Pinter pp. 590-607.

BTM (1999): World Market Update 1998. BTM Consult ApS. Ringkobing, Denmark.

Carlman, I. (1990): “Blåsningen. Svensk vindkraft 1973-1990”. Geografiska

Regionstudier Nr 23. Kulturgeografiska Institutionen vid Uppsala Universitet. (In Swedish).

Carlsson, B. (ed.) (1995): Technological systems and Economic Performance: The Case of Factory Automation. Kluwer Academic Publishers. Dordrecht, 1995.

Carlsson, B. (ed.) (1997): Technological Systems and Industrial Dynamics. Kluwer Academic Publishers. Norwell, Massachusetts.

Carlsson, B. and Jacobsson, S. (1991):

Carlsson, B. and Jacobsson, S. (1993): “Technological Systems and Economic Policy: The Diffusion of Factory Automation in Sweden”. Research Policy, 23 (3), 235-248.

Carlsson, B. and Jacobsson, S. (1997a): "Diversity Creation and Technological Systems: A Technology Policy Perspective”. In Edquist, C. (ed.): Systems of Innovation, Technologies, Institutions and Organizations. Pinter Publishers. London, 1997.

Carlsson, B. and Jacobsson, S. (1997b): "In Search of Useful Public Policies: Key Lessons and Issues for Policy Makers”. In Carlsson, B. (ed.): Technological Systems and Industrial Dynamics. Kluwer Academic Publishers. Norwell, Massachusetts, 1997.

Carlsson, B. and Stankiewicz, R. (1991): "On the Nature, Function and Composition of Technological Systems”. Journal of Evolutionary Economics, 1 (2), 93-118.

Curry, R. (1999): Photovoltaics Insider's Report, vol. 18, no. 2.

David, P. A. (1988): "Path-Dependency: Putting the Past into the Future”. Economic Series, Technical Report No 553, November. Stanford University, Institute for Mathematical Studies in the Social Sciences. 
Dosi, G. (1988): "Sources, Procedures and Microeconomic Effects of Innovation”. Journal of Economic Literature, 26 (3), 1120-1171.

Dosi, G., Pavitt, P. and Soete, L. (1990): The Economics of Technical Change and International Trade. Harvester/Wheatsheaf.

Edquist, C. (1997): Systems of Innovation: Technologies, Institutions and Organizations, Pinter, London.

Edquist, C. and Johnson, B. (1997): "Institutions and Organizations in Systems of Innovation”. In Edquist, C. (ed.): Systems of Innovation: Technologies, Institutions and Organizations, Pinter. London, 1997.

Ehrnberg, E. and Jacobsson, S. (1996): "Indicators of discontinuous technological change: an exploratory study of two discontinuities in the machine tool industry”. $R \& D$ Management, volume 27, number 2, April 1997 .

Ehrnberg, E. and Jacobsson, S. (1997): “Technological Discontinuities and Incumbent's Performance: An Analytical Framework”. In Edquist, C. (ed.): Systems of Innovation, Technologies, Institutions and Organizations, Pinter. London, 1997.

Ekvall, C., Pettersson, J., Sondén, D., Tenglund, P., Thunström, C. and Wallin, S. (1997): “Uponor: På väg mot solfångarbranschen”. Mimeo, Department of Industrial Dynamics, Chalmers University of Technology, Gothenburg. (In Swedish)

Eliasson, G. (1990):

Erickson, W. B. and Maitland I. (1989): "Healthy Industries and Public Policy”. In Dutton, M. E. (ed.): Industry Vitalization. Perganon Press. New York, 1989.

Esif (1995): Sun in action. The European Solar Industry Federation.

European Commission (1997a): White Paper on Renewable Energies COM 97-599 final.

European Commisson (1997b): Windenergy - the facts, volume 5. DirectorateGeneral for Energy.

Finanstidningen (1997): Finanstidningen, March 3, 1997. (In Swedish).

Fransman, M. (1990): The Market and Beyond. Cambridge University Press, Cambridge.

Galli, R. and Teubal, M. (1997): "Paradigmatic Shifts in National Innovation Systems”. In Edquist, C. (ed.): Systems of Innovation, Technologies, Institutions and Organizations. Pinter. London, 1997.

Granberg, A. (1997): "Mapping the Cognitive and Institutional Structures of an Evolving Advanced-Materials Field: The Case of Powder Technology”. In Carlsson, 
B. (ed.): Technological Systems and Industrial Dynamics. Kluwer Academic Publishers. Norwell, Massachusetts, 1997.

Grubb, ?. (1997):

Hansen, F. (1999): Interview with Finn Hansen, Managing Director of Tacke Windenergie, October 12.

Holm, M. (1997): “Vindkraft hotar fisket”. Dagens Nyheter 1997-08-22. (In Swedish).

Holmén, M. and Jacobsson, S. (1997): "Using patent analysis for identifying regional knowledge-based clusters”. Mimeo, Department of Industrial Dynamics, Chalmers University of Technology, Gothenburg.

Hughes, T. P. (1983): Networks of Power. The Johns Hopkins University Press. Baltimore.

Håkansson, H. (ed.) (1987): Industrial Technological Development, A Network Approach. Croom Helm. Bechenham.

Håkansson, H. (1989): Corporate technological behaviour, co-operation and networks. Routledge. London.

Jacobsson, S. (1997): “Sweden's Technological System for Electronics and Computer Technology”. In Carlsson, B. (ed.): Technological Systems and Industrial Dynamics. Kluwer Academic Publishers. Norwell, Massachusetts, 1997.

Johnson, A. and Jacobsson, S. (1999a): "Inducement and Blocking Mechanisms in the Development of a New Industry”. In Johnson, A., Renewable Energy Technology: A New Swedish Growth Industry? Thesis for the degree of Licentiate of Engineering. Department of Industrial Dynamics, Chalmers University of Technology. Gothenburg, 1999.

Johnson, A. and Jacobsson, S. (1999b): “The Emergence of a New Swedish Growth Industry: A Comparative Analysis of the Wind Turbine Industries in Sweden, Germany and The Netherlands”. Mimeo, Department of Industrial Dynamics, Chalmers University of Technology. Gothenburg, Sweden.

Kaiser, A. (1992): "Redirecting Power: Swedish Nuclear Power Policies in Historical Perspective”. Annu. Rev. Energy Environ., 17: 437-62.

Karnoe, P. and Garud, R. (1997): "Path Creation and dependence in the Danish wind turbine field”. To appear in: Porac, J. and Ventresca, M. (eds): Social Construction of Industries and Markets. Pergamon Press.

Kåberger, T. (1997): Personal communication with Tomas Kåberger, Department of Physical Resource Theory, Chalmers University of Technology. Gothenburg, Sweden. 
Lundvall, B.-Å. (ed.) (1992): National Systems of Innovations: Towards a Theory of Innovation and Interactive Learning. Pinter Publishers. London.

Lundgren, A. (1991): Technological Innovation and Industrial Evolution - the Emergence of Industrial Networks. Doctoral Dissertation. The Economic Research Institute, Stockholm School of Economics, Stockholm.

Lundgren, A. and Nordenlöw, L. (1995): "Mellan teknik och marknad - tekniskt entreprenörskap i industriella nätverk”. In Företag och marknader i förändring dynamik i nätverk. Nerenius och Santéren Förlag. Stockholm, 1995. (In Swedish).

Maskell. P. (1997): “Low-Tech Learning in the Furniture Industry”. In Eskelinen, H. (ed.): Regional Specialisation and Local Environment - learning and competitiveness, NordRefo, 1997:3. Stockholm.

Metcalfe, J. S. (1992): “The Economic Foundations of Technology Policy: Equilibrium and Evolutionary Perspectives”. Mimeo, University of Manchester.

Molly, J. P. (1999): Interview with J. P. Molly, head of DEWI (the German Wind Energy Institute), October 7.

Müller, D. (1999): Interview with Dirk Müller, Nordex, October 11.

Nelson, R. R. (1992): "National Innovation Systems: A Retrospective on a Study,” Industrial and Corporate Change, 1(2), 347-374.

Neij, L. (1997): Experience curves and the diffusion of solar cells and wind power. Paper presented at the workshop on Technological and Industrial Renewal of the Energy Sector, May 28-29, 1997, Särö, Sweden.

Nilsson, L. J. (1998): "Services Instead of Products: Experience from Energy Markets - Examples of Sweden”. In Meyer-Krahmer (ed.): Innovation and Sustainable Development. Lessons for Innovation Policies. Physica-Verlag. Heidelberg, 1998.

OECD (1997): OECD Energy Balance database. URL:

http://www.iea.org/stats/files/db/f_bal89.htm (Acc. 1997-08-12).

OECD (1998): OECD Total 1996. URL: http://www.iea.org/stats/files/table.htm (Acc.2000-01-14)

OECD/IEA (1997): IEA Energy technology R\&D Statistics 1974-1995. OECD/IEA. Paris Cedex, 1997.

Porter, M. (1990):

Saxenian, A. L. (1994): Regional Advantage. Culture and Competition in Silicon Valley and Route 128. Harvard University Press. Cambridge, Massachusetts. 
Schneider, S. and Goulder, L (1997): “Achieving low-cost emission targets”. Nature, vol. 389, 4 September, pp. 13-14.

STEM (1998): Energy in Sweden. Facts and Figures 1998. Swedish National Energy Administration. Stockholm.

Stirling, A. (1997):

UPVG (1994): Photovoltaics: On the Verge of Commercialisation, Summary Report, Utility Photovoltaic Group, Washington DC.

Westling (1997): Information received personally from Mr. Westling at a meeting at the University of Aalborg, May 1997.

Wigley, T.M.L.; Richels, R. and Edmonds, J.A. (1997): "Economic and environmental choices in the stabilization of atmospheric $\mathrm{CO}_{2}$ concentrations". Nature, vol. 379, 18 January, pp. 240-243. 